\title{
Applicability of Ground-based Remote Sensors for Crop N Management in Sub Saharan Africa
}

\author{
Jasper M. Teboh \\ School of Plant, Environmental, and Soil Sciences, Louisiana State University Agricultural Center \\ 238 Sturgis Hall, Baton Rouge, LA, 70803, USA \\ Tel: 1-701-306-9515 E-mail: JTeboh@agcenter.lsu.edu \\ Brenda S. Tubaña \\ School of Plant, Environmental, and Soil Sciences, Louisiana State University Agricultural Center \\ 309 Sturgis Hall, Baton Rouge, LA, 70803, USA \\ Tel: 1-225-578-9420Ｅ-mail: BTubana@agcenter.lsu.edu
}

\author{
Theophilus K. Udeigwe \\ Northeast Research Station, Louisiana State University Agricultural Center \\ P.O. Box 438, St. Joseph, LA 71366, USA \\ Tel: 1-225-715-3614 E-mail: tudeig1@tigers.lsu.edu \\ Yves Y. Emendack \\ Texas AgriLife Research \& Extension Center \\ Vernon 11708 Highway 70 South, Vernon, TX 76384, USA \\ Tel: 1-940-552-9941Ｅ-mail: yyemendack@ag.tamu.edu \\ Josh Lofton \\ School of Plant, Environmental and Soil Sciences, Louisiana State University \\ Baton Rouge, LA, 70803, USA \\ Tel: 1-918-346-7458Ｅ-mail: JLofton@agcenter.lsu.edu
}

Received: August 16, 2011

doi:10.5539/jas.v4n3p175

\author{
Accepted: August 30, $2011 \quad$ Online Published: December 29, 2011 \\ URL: http://dx.doi.org/10.5539/jas.v4n3p175
}

\begin{abstract}
Remote sensors have a growing legacy for improving crop $\mathrm{N}$ use efficiency (NUE) in several parts of the world. The technology employs crop spectral properties to determine fertilizer rates by matching crop $\mathrm{N}$ requirement based on midseason yield potential. Conclusions that the technology is inappropriate for Sub Saharan Africa (SSA) because the farmers use little or no fertilizer, or cannot afford it, are reviewed. Opportunities and applicability using a model concept from the GreenSeeker ${ }^{\circledR}$ sensor $(\$ 4000)$ are presented. Because farmers in SSA inefficiently apply fertilizer through blanket recommendations, they must improve crop NUE to minimize cost. Application of this technology would enable refinement or development of $\mathrm{N}$ recommendation protocols for target groups of farmers based on site and delineated management field zones. With new developments of a prototype GreenSeeker ${ }^{\circledR}$, the Optical Pocket Sensor $(<\$ 250)$, this technology will definitely be affordable and applicable, at least for institutional research purposes in SSA.
\end{abstract}

Keywords: Remote sensing, Nitrogen use efficiency, GreenSeeker ${ }^{\circledR}$, Sub Saharan Africa 


\section{Introduction}

Agricultural productivity gains have been a precursor to economic growth in about every developed economy. However, high fertilizer rates that were applied to maximize yields of improved varieties led to environmental pollution concerns (Howarth et al., 2002), magnified by declining nitrogen (N) fertilizer productivity between 1970 and mid 1980's; thence led to gradual reductions in N fertilizer applied across Europe (Koesling, 2005) and improved nitrogen use efficiency (NUE) from about 34 to 60\% (Frank, 2009). With renewed emphasis on improving crop NUE, precision agriculture applications were emerging, including Global Positioning System, and Geographic Information System (Shanahan et al., 2008). Remote sensing technologies were developed with ground-based sensing tools that use plant spectral properties (vegetative indices) to determine $\mathrm{N}$ status for making fertilizer recommendations. A prominent example is the GreenSeeker ${ }^{\mathbb{B}}$ (NTech Industries, Inc., Ukiah, $\mathrm{CA}$ ) integrated optical sensor used for determining crop $\mathrm{N}$ needs based on biomass, $\mathrm{N}$ status, and midseason predicted yield potential (Raun et al., 2005; Tubaña et al. 2010). Despite growing interests and encouraging prospects of remote sensing applications in South America and Asia, they are considered irrelevant in Sub Saharan Africa (SSA) because of low fertilizer input, small farm sizes, and unaffordability. Li et al., (2009) and Tubaña et al., (2008) showed GreenSeeker ${ }^{\mathbb{B}}$ sensor as an N management tool that can improve NUE with significant increase in net profits for cereal and grain crops. Compared with farmers' practice of pre-season input, Raun et al. (2002) reported a $15 \%$ increase in NUE with the sensor to variably apply $\mathrm{N}$ based on estimated midseason yield potential of wheat.

In SSA, fertilizer recommendations are based mostly on blanket application rates even though compelling evidence of common cross- and within-field spatiotemporal variability (Grover et al., 2009; Vanlauwe et al., 2007) often results in inadequate application rates (Oikeh et al., 2008b; Okeleye, 2009). The range of soil $\mathrm{N}$ supplying capacity on farmers' fields is often too wide to depend on current recommendation approaches. Some of the practices to improve NUE have failed because some fertilizer recommendations prescribe up to three fertilizer top dressings to match crop needs (Kamanga et al., 2001). In SSA, soil testing fees can be quite high, representing up to $22 \%$ of total variable cost and $58 \%$ of the fertilizer cost of production (Gandonou, 2005). With the pace of developing improved varieties slowing as earlier varieties approach maximum yielding capacities (Duvick et al., 1999; Mann, 1997), and potential success of producing N fixing plants still a challenge, relying on improved varieties alone is not quite viable for SSA farmers. More so, attempts aimed at developing new crop varieties that utilize low $\mathrm{N}$ to maintain current yields are conflicting with the objective to improve protein content of foods produced in Africa.

Despite numerous challenges for remote sensing technology in SSA, generalizing impracticality across the region is true only if their practical necessity is based primarily on its impact on the very poor, or on their immediate yields and cost; rather than as a research and development tool for building new knowledge for informed fertilizer management decision making and planning. Against this backdrop we present an overview of opportunities and challenges of prospective integration of the GreenSeeker ${ }^{\circledR}$ remote sensor concept as an $\mathrm{N}$ decision support tool in SSA. This review has been organized to address the state of fertilizer use in SSA, the challenges and opportunities of adopting GreenSeeker ${ }^{\mathbb{B}}$ remote sensor technology as an $\mathrm{N}$ decision support tool in SSA, and an attempt to partially reconcile the notion that precision agriculture technologies are irrelevant in SSA.

\section{Context of $\mathbf{N}$ fertilizer use and management in SSA}

There are increasing trends in fertilizer use in SSA since the decline following structural adjustments and agricultural reforms in the 1990s. During these reforms grain output growth was attributed mostly to land expansion rather than yield increase (Shapouri \& Rosen, 2006). As a result, a common problem for the region had been the rate of nutrient depletion. In low-fertilizer input use countries such as Rwanda, Tanzania, Mozambique and Niger, the equivalence of nutrient depletion was reported to be about $25 \%$ of the agricultural GDP, estimated at US \$4 billion year ${ }^{-1}$ representing an average 7\% nutrient depletion in SSA (Drechsel et al., 2001). Even though legumes constitute an important source of $\mathrm{N}$ for most small farm holdings, management approaches in fertilizer-based systems can out-perform the synchrony achieved in legume-based crop rotations (Crews \& Peoples, 2005) or residue applications by as much as $159 \%$ residue $\mathrm{N}$ equivalency (Baijukya et al., 2006). Synchrony between plant $\mathrm{N}$ demand and uptake is jeopardized by commonly practiced field tillage, which hypothetically, induces $\mathrm{N}$ flush and leaching early in the season (Govaerts \& Verhults, 2005). Consequently, failure to consider aggregate effects of field characteristics and climatic variability on crop yield potential, at least temporarily as expressed by plant growth, is likelihood for poor farmer adoption of some fertilizer input technologies when yields fail to respond to $\mathrm{N}$ input. 


\section{Constraints to farmers' $\mathbf{N}$ input decisions in SSA}

Many factors account for low fertilizer use in SSA including, affordability, subsistence farming, household organic waste and plant residue, resource endowment, $\mathrm{N}$ value cost ratio, disconnect between farmers, and the researcher and extension agents. Some farmers mythically believe that if they use fertilizer and later stopped its application, inorganic fertilizer would render their soils unproductive and result in significant drop in yields if not applied the following year (Galdwin, 1991; Vanlauwe \& Giller, 2006). Fundamental to these constraints had been the misperception even amongst policy makers that fertilizer is primarily a productivity-enhancing input rather than an important component of the national economic development framework. With recent shift in this knowledge paradigm, new efforts to increase fertilizer input will likely add to present predicaments if efforts limited to agroforestry system technologies ignore alternative and innovative approaches that can synergistically improve NUE. Remote sensing technologies use decision support tools that account for soil $\mathrm{N}$ and environmental variability when making rate recommendations to optimize crop NUE (Martin et al., 2007). The benefits of this technology are envisaged for relatively younger farmers who are more educated and open to innovations, have medium to large farm sizes, have better access to research and extension services, and have shown better loan repayment records (Afolabi, 2010; Oboh \& Ekpebu, 2011).

\section{Ground-based remote sensors for managing plant NUE}

Commercial optical sensing tools have been used successfully to determine plant $\mathrm{N}$ status and guide input decisions (Table 1). Associated drawbacks with some of these sensors include: reliance on solar radiation by the passive sensors, cost, level of sophistication, and timeliness. Some sensors produce insufficient spectral resolutions, and need to develop $\mathrm{N}$ recommendation maps (Erdle et al., 2011; Govaerts et al., 2007). The GreenSeeker $^{\circledR}$ and Crop Circle ${ }^{\mathrm{TM}}$ (Holland Scientific, Inc., Lincoln, NE, USA) are two prominent ground-based remote sensors in use today. However, growing extent of use across geographies and crops, the development of new low cost prototypes of the former, and the potential for low variability relative to other sensors are underpinning reasons to review the relevance of GreenSeeker ${ }^{\mathbb{B}}$ applications in SSA agriculture.

\subsection{The GreenSeeker ${ }^{\circledR}$ sensor as an N-decision support tool}

Sensor-based $\mathrm{N}$ management is credited for using non-destructive applications to provide information on crop health within timescale constraints, and quantify spatial crop $\mathrm{N}$ variability based on $\mathrm{N}$ status. Plant chlorophyll content is related to growth stage, photosynthate production and plant stress (Ustin et al., 1998), while plant canopy spectral reflectance is related to photosynthesis (Tian et al., 2005). The GreenSeeker ${ }^{\circledR}$ is an active sensor that emits its own light to measure canopy reflectance corresponding to the red $(671 \pm 10 \mathrm{~nm})$ and near infrared $(780 \pm 10 \mathrm{~nm}$ ) light bandwidths (Tubana et al., 2008). Active sensors have the advantage of minimizing the influence of heterogeneous light intensity due to solar azimuth angle on plant canopies. This means the Normalized Difference Vegetation Index (NDVI), which is a measure of canopy reflectance, would for passive sensors vary with solar angle, amount of clouds, and view position. GreenSeeker ${ }^{\circledR}$ sensor readings are taken 0.6 to $1 \mathrm{~m}$ above crop canopy, registering about 1000 value outputs per second, and covering area of $0.1 \times 0.6 \mathrm{~m}^{2}$. High reflectance within the NIR region indicates amount of healthy biomass. Low reflectance from the red band (associated with photosynthetically active radiation) or strong absorption in the visible region of the spectrum indicates high chlorophyll content (Fig. 1) hence N status. This indicates N uptake, plant health, and is predictive of yield. Therefore, leaf reflectance in the visible spectrum increases with $\mathrm{N}$ deficiency but as the wavelength changes from short (red) to long (NIR) denoted by the steep gradient (the red edge), leaf reflectance decreases in the near infrared region as shown on Figure 1 (Heege et al., 2008).

\subsection{Developing the $N$ fertilizer optimization algorithm (NFOA)}

Algorithms for determining $\mathrm{N}$ rates for several crops and locations have been established (Holzapfel et al., 2009). They can be used in a sensor based $\mathrm{N}$ rate calculator (SBNRC) developed by researchers at Oklahoma State University (OSU) to input zone-specific sensor readings for calculating in-season crop yield level and $\mathrm{N}$ response index (RI). The sensor based $\mathrm{N}$ rate recommendation algorithm is defined as (Raun et al., 2002);

$$
\mathrm{N}_{\text {rate }}=\frac{[(\mathrm{YP} 0 * \mathrm{RI})-\mathrm{YP} 0] * \% \mathrm{~N}}{\mathrm{NUE}}
$$

\subsubsection{Yield potential (YP0)}

It is the maximum obtainable crop yield with no added $\mathrm{N}$. Considered the cornerstone of any $\mathrm{N}$ fertilizer rate determination, YP0 was shown to be predicted by in-season estimates of yield (INSEY) (Lukina et al., 2001; Raun et al., 2002). Yield potential is given by, 


$$
\mathrm{YP0}=\mathrm{Ae}^{-\mathrm{b}} \frac{\mathrm{NDVI}}{\mathrm{GDD}}
$$

Where, $\mathrm{A}$ and $\mathrm{b}$ are a function of crop and site and are determined from an exponential function relating potential yield to NDVI for days of active plant growth (Raun et al., 2002; Teal et al., 2006).

And, INSEY $=\frac{\text { NDVI }}{\text { GDD }}$

Where, GDD is the number of growing degree days greater than zero from seeding (or seed emergence) to sensing. The INSEY provides an estimate of daily biomass production or growth rate (Raun et al., 2005) and is therefore an important determinant of final grain yield. Its determination usually coincides with the stage at which $\mathrm{N}$ uptake is the most optimal, usually between V8 and V12 for corn (Fig. 2). The GDD is computed as:

$$
\mathrm{GDD}=\left[\left(\frac{\mathrm{Tmax}+\mathrm{Tmin}}{2}\right)-\text { Base temperature }\right]>0
$$

Where Tmax and Tmin are maximum and minimum atmospheric temperatures. Base temperature is the minimum temperature required for a crop to grow.

\subsubsection{Nitrogen response index (RI)}

Response index is the ratio of NDVI recorded from a non-N limiting plot to that of a non-N treated plot whose value (determined at midseason) indicates likelihood and magnitude of increase in crop growth with added $\mathrm{N}$. It is based on the concept that the amount of $\mathrm{N}$ to apply at a given location can be calculated by comparing spatial crop growth differences of an $\mathrm{N}$-reference strip ( $\mathrm{N}$ sufficient) to differences of farmers' practice within each management zone. The N-reference strip is a representative section of an entire field that is adequately fertilized to achieve maximum yield potential. Comparing $\mathrm{N}$-sufficient plot with non-N treated plots is also necessary because sensor output (NDVI) needs to be normalized (adjusted) to the N-reference plot to account for any color development not associated with $\mathrm{N}$ stress. Therefore at mid-growing season, magnitude of response to $\mathrm{N}$ input can be obtained, and the $\mathrm{N}$ rate determined based on potential yield. Johnson and Raun (2003) first described yield response to added $\mathrm{N}$ as the ratio of yield of an $\mathrm{N}$-reference plot to that of a non-N treated plot given by,

$$
\mathrm{RI}_{\text {Harvest }}=\frac{\text { Yield }_{\mathrm{N}-\text { Reference strip }}}{\text { Yield }_{\text {Farmer's rate }}}
$$

Mullen et al. (2003) later showed that the ratio of NDVI from the N-reference plot to NDVI of a farmer's rate or control plot $\left(\mathrm{RI}_{\mathrm{NDVI}}\right)$ could be used to predict $\mathrm{RI}_{\text {Harvest }}$. High unpredictable year to year variability of $\mathrm{RI}$ and environmental influence on grain YP0, result to low relationship between the two (Raun et al., 2011). They further stressed the importance of RI and YP0 in determining fertilizer N rates because they both affect crop N demand, implying high crop response to $\mathrm{N}$ does not mean high yields.

\subsubsection{Nitrogen use efficiency (NUE) and \% $\mathrm{N}$}

The amount of $\mathrm{N}$ input recommended that corresponds to the fraction of $\mathrm{N}$ taken up to meet additional yield demands is determined by crop NUE. Values for grain $\mathrm{N}$ content $(\% \mathrm{~N})$ per yield of harvested grain vary by region, and can be obtained from recent publications for each crop.

\subsection{Economic benefits of implementing the sensor based $N$ rate concept}

The necessity to improve NUE in SSA is a consequence of prohibitive fertilizer costs and unintended environmental consequences. By linking midseason crop yield performance with appropriate fertilizer rate, yields can be maintained or increased by lower or higher $\mathrm{N}$ recommendation, up to the maximum YP0, thereby optimizing financial return, minimizing financial and environmental cost (Isaac \& Kimaro, 2011). For example, the ability to predict midseason yield potential means farmers will have the opportunity to modify $\mathrm{N}$ recommendation such that when plants are under stress (and are likely unable to recover their yield potentials), application rates should be lowered and vice versa. This is under the assumption that in both scenarios, RI is the same/comparable. Thus RI is an important cost-saving information guide to minimize Type II errors by suggesting a need to apply N only when crops necessarily need it (Johnson \& Raun, 2003; Mullen et al., 2003). Hodgen et al. (2005) determined that when,

$1<\mathrm{RI}<1.1, \mathrm{~N}$ application will likely be non-responsive

$1.1<\mathrm{RI}<1.25, \mathrm{~N}$ application will likely be marginally responsive 
$\mathrm{RI}>1.25, \mathrm{~N}$ application will be responsive

Where, marginal yield response to additional $\mathrm{N}$ application means cost benefit ratio of yield gains to added fertilizer is likely uneconomical; mainly because market prices of the crop may be too low to yield significant profits from the $25 \%$ yield increase. While most farmers are believed to have good knowledge of spatial yield variability in their fields, they are often less knowledgeable to determine how much fertilizer to reduce or add to low or high yielding areas, respectively. This information is provided by RI and INSEY.

\subsection{Agronomic benefits of implementing the sensor based $N$ rate concept}

Crop growth monitoring is non-destructive when using remote sensing technology. The NFOA ensures that prescribed fertilizer rate results to net return to $\mathrm{N}$ use (agronomic efficiency) cresting at levels that contribute at a maximum to improving efficiencies of all other inputs. Another reason why midseason yield goal approaches have gained wide recognition is because pre-plant established yield goal approaches to $\mathrm{N}$ management are more likely to over or underestimate $\mathrm{N}$ recommendations (Mulvaney et al., 2004). This approach is used in parts of SSA (Nel \& Bloem, 2007) where it is less efficient because it uses $\mathrm{N}$ response functions which define an optimal $\mathrm{N}$ rate for which the marginal productivity of $\mathrm{N}$ is zero (Jaynes, 2011). As a result, available $\mathrm{N}$ is more likely to correlate poorly with yields (Nel \& Bloem, 2007) due to annual climatic fluctuations and soil N supply (Kahabka et al., 2004; Scharf, 2001). One explanation for using yield goal concept is its suitability for agroenvironments where contribution of $\mathrm{N}$ through mineralization of soil organic matter is insufficient to significantly cause reduction in $\mathrm{N}$ rates to attain seasonal crop yield potential (Derby et al., 2004). Unlike in northern USA (e.g. North Dakota, Minnesota, South Dakota) where long durations of low soil temperatures following winter may explain low rapid organic matter turnover and $\mathrm{N}$ mineralization, rates of soil organic $\mathrm{N}$ conversion in SSA can be quite significant. This can engender radical year to year changes in crop response (Johnson \& Raun, 2003) especially for highly organic and intensively cultivated soils. Notwithstanding, fertilizer rates should match crop needs based not only on soil $\mathrm{N}$ contributions, but also on other environmental conditions influencing final yield. To know how wide the gap is between current crop yield and its potential is a likely inevitable accompaniment to efficient target management decisions. Potential yield analysis data for major cereal crops (corn, wheat, rice) in SSA are rare. To this extent it is quite challenging to estimate current yield gaps across farming regions and to determine by how much, if yields must be increased to narrow the gaps to meet projected demands. However, documenting midseason crop growth information is potentially a critical indicator of future yield slowdown, especially if used in developing integrated management programs with information from soil, and crop models. This presents an opportunity for making realistic regional yield projections for the future by comparing present yields to their yield potentials. By developing databases from relationships between fertilizer input and potential yields, analytical tools can be refined, thereby increasing agronomic knowledge at local levels.

Unlike in the US and Europe where, farm sizes are generally large, medium to large size farms in SSA ( $1-2$ ha to above 5 ha) are well suited for on-farm trials and applications with the handheld remote sensors because of available cheap labor to substitute for mechanical application of fertilizer rates.

\subsection{Case studies of use of the GreenSeeker ${ }^{\circledR}$ remote sensor}

The NFOA concept has been used in extensive research and applications in Asia where, collaborative work between the Indian Ministry of Agriculture, Oklahoma State University (OSU), and the International Maize and Wheat Improvement Center (CIMMYT) have let to the development of a SBNRC. In the Indo-Gangetic Plain of Northwestern India (South East Asia), high correlations were observed for wheat yield in response to sensor-based N prescription at Feekes stages 5-6 or 7-8 (Bijay-Singh et al., 2011). Other study sites include Central Asia (Kienzler et al., 2009), in Kazakhstan, Kyrgyzstan, Tjikistan, Turkmenistan, and Uzbekistan, where regional algorithms are being establishment. In China, wheat NUE was improved by $10 \%$ when compared to soil $\mathrm{N}$-based tests (NUE $=51 \%$ ), and by $13.1 \%$ based on farmers' practice ( $\mathrm{Li}$ et al., 2009). In South America, Govaerts et al. (2007) and Velhurst et al. (2011) reported the GreenSeeker ${ }^{\circledR}$ sensor to be an effective tool for monitoring and evaluating crop spatial variability for cultivation practices relating to tillage and crop residue management in Mexico. In Scotland, Europe, McKenzie et al. (2009) used canopy greenness from GreenSeeker ${ }^{\mathbb{B}}$-generated NDVI to identify barley genotype response to sub-soil water access by roots. In France, the GreenSeeker ${ }^{\circledR}$ was linked to a GPS to plot NDVI maps of a vineyard to measure gap fraction, the proportion of transmitted radiation not intercepted by foliage in a range of azimuthal directions (Drissi et al., 2009).

Reports of farmers' testimonies of the economic benefits from employing SBNRC are available online (http://nue.okstate.edu/International/GreenSeeker.htm). Spectral reflectance of field weed was useful for characterizing the efficacy of herbicide application (Zhang et al., 2010) in Texas. Tubana et al. (2011) also showed improvement of NUE with midseason $\mathrm{N}$ decision tools as well as highlighting potentials to update 
current algorithm accounting for site variability in Louisiana and Mississippi. In a semi arid region in Colorado, Shaver et al. (2011) showed high coefficients of determination explained variability of corn grain yield at V12 and V14.

Some work has been carried out in Africa (Kenya, Zimbabwe, Ethiopia, South Africa), where improved N use management can be quite benefitial to farmers. A training workshop held in Kenya led to the development of a SBNRC by the Dominion Farms and OSU; and in Zimbabwe by CIMMYT and the Zimbabwe National Program. GreenSeeker ${ }^{\circledR}$ has been used to identify desirable grass species in South Africa (Shaker et al., 2009). Obvious challenges (Table 2) to potential adoption of remote sensing technologies, even following years of research and validation, are envisaged. However, current and future opportunities that exist cannot be overlooked.

\section{Opportunities for application of sensor-based $N$ recommendations in SSA}

Remote sensing research opportunities are envisaged from shortcomings associated with soil based fertilizer recommendations in SSA, where problems of transportation to nearest soil testing facilities can seriously affect handling and storage. These practical constraints and limitations to operationally defined soil handling and storage procedures following field sampling can introduce significant differences in $\mathrm{N}$ concentrations due to $\mathrm{N}$ speciation during transportation and storage (Mian et al., 2011). The implication of mishandling soil and the resulting analysis is that inadequate $\mathrm{N}$ fertilizer recommendation rates are made. To circumvent $\mathrm{N}$ speciation problems given that drying soil samples can increase soil $\mathrm{N}$ analysis (Miransari \& Mackenzie, 2011), on-site treatment of soil with extractant was suggested (Mian et al., 2011). This practice has not gained much, if any, significant traction.

\subsection{Myths and generalizations}

Contrary to popular myths generalizing low fertilizer input by farmers across SSA, and their conclusive irrelevancy of precision agriculture using remote sensing, some studies have shown that in parts of SSA, farmers apply as much fertilizer as their contemporaries in East and South Asia. Ariga et al. (2006) reported that since the liberalization of the fertilizer market sector in early 1990's there has been a 35\% increase in fertilizer use in Kenya, by over 1300 smallholder farmers periodically surveyed from 1995 to 2004. The proportion of smallholder farmers applying fertilizer ranged from $10 \%$ of households to $85 \%$, at the rate of $163 \mathrm{~kg} \mathrm{ha}^{-1}$ especially for the Western and Central high-potential corn cultivation areas with attractive cost benefit ratios. In recent years, fertilizer use in Ethiopia has risen from $21 \mathrm{~kg} \mathrm{ha}^{-1}$ between $1991-95$ nationally, to $35 \mathrm{~kg} \mathrm{ha}^{-1}$ in 1999, and now up to $81 \mathrm{~kg} \mathrm{ha}^{-1}$ for $45 \%$ of total farmland receiving fertilizer (Zerfu \& Larson, 2010). In 2004, survey of farmers showed failure to follow the Ethiopian Agricultural Research Institute urea recommendations of $200 \mathrm{~kg} \mathrm{ha}^{-1}$ in split applications. The likelihood of rejection of recommended rates even after one-time applications that ranged between 116-167 kg ha-1 of the $200 \mathrm{~kg} \mathrm{ha}^{-1}$ prescribed (Zerfu \& Larson, 2010) are expected due to poor synchrony, fertilizer loss, and high cost to benefit ratios. In Zambia, National Extension recommendation rates for urea have been reported at $200 \mathrm{~kg} \mathrm{~N}^{-1}$ as basal rate, and another $200 \mathrm{~kg} \mathrm{~N}^{-1}$ as top dress. In 1999/2000 and 2002/2003, standard extension recommended fertilizer rates of $116 \mathrm{~N} \mathrm{~kg} \mathrm{ha}^{-1}$ were much higher than rates $\left(44-71 \mathrm{~kg} \mathrm{ha}^{-1}\right)$ necessary to achieve profitable marginal value cost ratios in relatively highly productive zones in Zambia (Xu et al., 2009). Annual application of $100 \mathrm{~kg} \mathrm{~N} \mathrm{ha}^{-1}$ in intensively cultivated corn and vegetable in South Western Nigeria (Ogun State) resulted to almost a third of the fertilizer applied, lost to underground water contamination (Adetunji, 1994). These, and likely other undocumented or unpublished data are indicative of potentially useful technologies unavailable to essential target groups in SSA.

\subsection{Newly developed prototype of the GreenSeeker ${ }^{\circledR}$ sensor}

Research efforts to develop more affordable and portable handheld sensors that meet required and uncompromising performance standards of the GreenSeeker ${ }^{\mathbb{B}}$ sensor have been reported (Raun et al, 2011). Large numbers of pocket sensors are currently used on farmers' fields to confirm acceptable results (Raun et al., 2011). However, they cautioned that the commercial pocket sensor (about \$250) does not replace the GreenSeeker ${ }^{\circledR}$ sensor, but presents comparative price advantage and attainability for use in SSA. It is therefore possible that as prices become more affordable, researchers in SSA would use them to generate relevant results that are useful in formulating fertilizer rates, to the extent of influencing policies on fertilizer based management.

\section{Summary}

Fertilizer recommendations in SSA are mostly inefficient because application rates are neither crop-demand specific nor current with associated yields, and therefore minimize the influence of temporal changes that affect final yields. Farmers' management decisions to optimize fertilizer use can be enhanced if present tendencies were reversed to establish congruency between crop $\mathrm{N}$ demand and $\mathrm{N}$ use. The use of remote sensors to measure 
crop canopy reflectance, synonymous to crop $\mathrm{N}$ content, biomass and vigor, has been an important development for managing crop $\mathrm{N}$ and use efficiency. By using crop spectral properties, response indices can be measured and potential yield determined at midseason to develop an optimal $\mathrm{N}$ rate algorithm and a fertilizer rate calculator for making site specific $\mathrm{N}$ recommendations; hence synchronizing $\mathrm{N}$ application with crop demand to maximize $\mathrm{N}$ uptake, minimize loss, and optimize returns. We showed relevance of the sensor based technology for farmers in SSA, especially the young and educated farmers. We contrasted common folklore beliefs that remote sensing technology is only applicable to industrialized farming.

Unlike on-the-go variable rate application in mechanized and advanced systems, a suitable approach for SSA is the use of management zones. By collecting sensor data from relatively homogenized management zones representing farmers' practice, and comparing to a non-limiting $\mathrm{N}$ reference strip within each zone, response indices can be calculated to determine application requirement. Nitrogen rate calculator available online can be used to input zone delineated sensor data. Encouragingly, a newly developed and tested pocket sensor, a prototype of the GreenSeeker ${ }^{\mathbb{B}}$, is much cheaper and commercially available. The basis for developing any research on modern technology uniquely aimed at satisfying the needs of the very poor and potentially the least educated farmers in Africa would likely be unsuccessful. As suggested by the decomposed theory of planned behavior, predictive behaviors of farmers' response to new technologies are often determined by model farmers who often are more educated, more inclined to adopt new technologies, have mid- to large-size farms, are more risk averse, and often apply higher inputs. This review therefore explains existing opportunities for the handheld remote sensor technology to fill an existing gap in $\mathrm{N}$ management, at least in synergy with ongoing $\mathrm{N}$ management research and decision support tools in SSA. We recommend that for any sensor based technology to gain cutting edge practical applications within the context of SSA farming; its success should not be limited to the extent of farmers' immediate adoption of the technology (Zamykal \& Everingham, 2009). It should in addition, consider opportunities to provoke researchers to develop new protocols, or to review current fertilizer recommendation protocols for farmers in SSA. However, any meaningful development of a sensor based $\mathrm{N}$ management in SSA would need well structured institutional support.

\section{References}

Adetunji, M.T. (1994). Nitrogen application and underground water contamination in some agricultural soils of South Western Nigeria. Fertil. Res., 37(2), 159-163. http://dx.doi.org/10.1007/BF00748556

Afolabi, J.A. (2010). Analysis of loan repayment among small scale farmers in Oyo State, Nigeria. J. Soc. Sci., 22(2), 115-119.

Alam, M.M., Ladha, J.K. Rahman, K.S., Foyjunnessa, Harun-ur-Rashid, Khan, A.H., \& Buresh, R.J. (2005). Leaf color chart for managing nitrogen fertilizer in lowland rice in Bangladesh. Agron. J., 97(3), 949-959. http://dx.doi.org/10.2134/agronj2004.0206

Ariga, J., Jayne, T.S., \& Nyoro, J. (2006). Factors driving the growth in fertilizer consumption in Kenya, 1990-2005: Sustaining the momentum in Kenya and lessons for broader replicability in Sub-Saharan Africa. Tegemeo Working Paper 24/(2006). Tegemo Institute of Agricultural Policy and Development, Nairobi, Kenya. pp.59.

Baijukya, F.P., de Ridder, N., \& Giller, K.E. (2006). Nitrogen release from decomposing residues of leguminous cover crops and their effect on maize yield on depleted soils of Bukoba District, Tanzania. Plant Soil, 279(1-2), 77-93. http://dx.doi.org/10.1007/s11104-005-2504-0

Berntsen, J., Thomsen, A., Schelde, K., Hansen, O.M., Knudsen, L., Broge, N., Hougaard, H., \& Hørfarter, R. (2006). Algorithms for sensor-based redistribution of nitrogen fertilizer in winter wheat. Precision Agric., 7 , 65-83. http://dx.doi.org/10.1007/s11119-006-9000-2

Bijay-Singh, Sharma, R.K., Jaspreet-Kaur, Jat, M.L., Kent, M.L., et al. (2011). Assessment of the nitrogen management strategy using an optical sensor for irrigated wheat. Agron. Sustain. Dev., 31(3), 589-603. http://dx.doi.org/10.1007/ s13593-011-0005-5

Bowen, T.R., Hopkins, B.G., Ellsworth, J.W., Cook, A.G., \& Funk, S.A. (2005). In-season variable rate N in potato and barley production using optical sensing instrumentation. In W.B., Stevens, (Ed.), Western Nutrient Management Conference Proceedings. 6, 141-148. Salt Lake City, UT, USA: Potash and Phosphate Institute.

Cartelat, A., Cerovic, Z.G., Goulas, Y., Meyer, S., Lelarge, C., Prioul, J-L., Barbottin, A., Jeuffroy, M-H., Gate, P., Agati, G., \& Moya, I. (2005). Optically assessed contents of leaf polyphenolics and chlorophyll as indicators of nitrogen deficiency in wheat (Triticum aestivum L.). Field Crops Res., 91, 35-49. http://dx.doi.org/10.1016/j.fcr.2004.05.002 
Cook, S.E., O'Brien, R., Corner, R.J., \& Oberthur, T. (2003). Is precision agriculture relevant to developing countries? In J. Stafford, \& A. Werner (Eds.) Proceedings of the $4^{\text {th }}$ European Conference on Precision Agriculture, (pp. 115-119). Berlin, Germany: Wageningen Academic Publishers, The Netherlands.

Crews, T.E. \& Peoples, M.B. (2005). Can the synchrony of nitrogen supply and crop demand be improved in legume and fertilizer-based agroecosystems? A review. Nutr. Cycl. Agroecosys, 72(2), 101-120. http://dx.doi.org/10.1007/s10705-004-6480-1

Daberkow, S.G., \& McBride, W.D. (2000). Adoption of precision agriculture technologies by U.S. farmers. In P.C. Robert et al. (Eds.) Proceedings of the $5^{\text {th }}$ International Conference on Precision Agriculture, 16-19 July, 2000. Minneapolis, MN., USA.

Derby, N.E., Casey, F.X.M., Knighton, R.E., \& Steele, D.D. (2004). Midseason nitrogen fertility management for corn based on weather and yield prediction. Agron. J., 96, 494-501. http://dx.doi.org/10.2134/agronj2004.4940

Drechsel, P., Gyiele, L., Kunze, D., \& Cofie, O. (2001). Population density, soil nutrient depletion, and economic growth in Sub-Saharan Africa. Ecol. Econ., 38, 251-258. http://dx.doi.org/10.1016/S0921-8009(01)00167-7

Drissi, R., Goutouly, J-P., Forget, D., \& Gaudillere, J-P. (2009). Nondestructive Measurement of grapevine leaf area by ground normalized difference vegetation index. Agron. J., 101(1), 226-231. http://dx.doi.org/10.2134/agronj2007.0167

Duvick, D.N., \& Cassman, K.G. (1999). Post-green revolution trends in yield potential of temperate maize in the north-central United States. Crop Sci., 39, 1622-1630.

Erdle, K., Mistele, B., \& Schmidhalte, U. (2011). Comparison of active and passive spectral sensors in discriminating biomass parameters and nitrogen status in wheat cultivars. Field Crops Res., 124(1), 74-84.

Frank, B. (2009). The impact of mineral fertilizers on the carbon footprint of crop production. In The Proceedings of the International Plant Nutrition Colloquium XVI, UC, Davis., CA. XVI. Retrieved July 19, 2011.

Freeman, K.W., Arnall, D.B., Mullen, R.W., Girma, K., Martin, K.L., Teal, R.K., \& Raun, W.R. (2007). By-plant prediction of corn forage biomass and nitrogen uptake at various stages using remote sensing and plant height measures. Agron. J., 99(2), 530-536. http://dx.doi.org/10.2134/agronj2006.0125

Gandonou, J-M.A. (2005). Essays on precision agriculture technology adoption and risk management. Ph.D. Dissert., the College of Agriculture at the University of Kentucky, USA. http://hdl.handle.net/10225/64

Govaerts, B., Sayre, K.D., \& Deckers, J. (2005). Stable high yields with zero tillage and permanent bed planting? Field Crops Res., 94(1), 33-42.

Govaerts, B., Verhulst, N., Sayre, K.D., De Corte, P., Goudeseune, B., Lichter, K., Crossa, J., Deckers, J., \& Dendooven, L. (2007). Evaluating spatial within plot crop variability for different management practices with an optical sensor? Plant Soil, 299(1-2), 29-42. http://dx.doi.org/10.1007/s11104-007-9358-6

Grover, K.K., Karsten, H.D., \& Roth. G.W. (2009). Corn grain yields and yield stability in four long-term cropping systems. Agron. J., 101(4), 940-946. http://dx.doi.org/10.2134/agronj2008.0221x

Hartz, T.K., Johnstone, P.R., Williams, E., \& Smith, R.F. (2007). Establishing lettuce leaf nutrient optimum ranges through DRIS analysis. Hort. Science, 42(1), 143-146.

Heege, H.J., Reusch, S., \& Thiessen, E. (2008). Prospects and results for optical systems for site-specific on-the-go control of nitrogen-top-dressing in Germany. Precision Agric., 9(3), 115-131. http://dx.doi.org/10.1007/s11119-008-9055-3

Hodgen, P.J., Raun, W.R., Johnson, G.V., Teal, R.K., Freeman, K.W., Brixey, K.B., Martin, K.L., Solie, J.B., \& Stone, M.L. (2005). Relationship between response indices measured in-season and at harvest in winter wheat. $J$. Plant Nutr., 28(2), 221-235. http://dx.doi.org/10.1081/PLN-200047605

Holzapfel, C.B., Lafond, G.P., Brandt, S.A., Bullock, P.R., Irvine, R.B., Morrison, M.J., May, W.E., \& James, D.C. (2009). Estimating canola (Brassica napus L.) yield potential using an active optical sensor. Canadian J. Plant Sci., 89(6), 1149-1160. http://dx.doi.org/10.4141/CJPS09056 
Howarth, R.W., Sharpley, A., \& Walker, W. (2002). Sources of nutrient pollution to coastal waters in the United States- Implications for achieving coastal water quality goals. Estuaries, 25(4b), 656-676. http://dx.doi.org/10.1007/BF02804898

Huang, J.L, He, F. \& Cui, K.H. (2008). Determination of optical nitrogen rate for rice varieties using a chlorophyll meter. Field Crops Res., 105, 70-80. http://dx.doi.org/10.1016/j.fcr.2007.07.006

Jaynes, D.B. (2011). Confidence bands for measured economically optimal nitrogen rates. Precision Agric., 12(2), 196-213. http://dx.doi.org/10.1007/ s11119-010-9168-3

Kienzler, K., Saparov, A., Bekenov, M., Kholov, B., Nepesov, M., Ikramov, R., Khusanov, R., Mirzabaev, A., de Johnson, G.V. \& Raun, W.R. (2003). Nitrogen response index as a guide to fertilizer management. J. Plant Nutr., 26(2), 249-262. http://dx.doi.org/10.1081=PLN-120017134

Kahabka, J.E., Van Es, H.M., McClenahan, E.J., \& Cox, W.J. (2004). Spatial analysis of maize response to nitrogen fertilizer in Central New York. Precision Agric., 5(5), 463-476. http://dx.doi.org/10.1007/s11119-004-5320-2

Kamanga, B.C.G., Shamudzarira, Z., \& Waddington, S.R. (2001). On-farm comparison of fertilizer application practices to access nitrogen-use efficiency with maize in Zimuto Communal Area, Zimbabwe. Proceedings of the $7^{\text {th }}$ Eastern and Southern African conference, 11-15 Feb., pp. 519-529.

Kitchen, N.R., Sudduth, S.T., Drummond, K.A., Scharf, P.C., Palm, H.L., Roberts, D.F., \& Vorie, E.D. (2010). Ground-based canopy reflectance sensing for variable-rate nitrogen corn fertilization. Agron. J., 102(1), 71-84. http://dx.doi.org/10.2134/agronj2009.0114

Koesling, M. (2005). Development of nitrogen fertilisers used in agricultural production. In J.J. Schroeder, \& J.J. Neeteson (Eds.) $N$ management in agroecosystems in relation to the water framework directive. Proceedings of the $14^{\text {th }} \mathrm{N}$ Workshop, Oct. 2005. (pp. 30-32). MaastReferencet, The Netherlands.

Kuckenberg, J., Tartachnyk, I., \& Noga, G. (2008). Evaluation of fluorescence and remission techniques for monitoring changes in peel chlorophyll and internal fruit characteristics in sunlit and shaded sides of apple fruit during shelf-life. Post Harvest Technol., 48(2), 231-241. http://dx.doi.org/10.1016/j.postharvbio.2007.10.013

Kutter, T., Tiemann, S., Siebert, R., \& Fountas, S. (2009). The role of communication and co-operation in the adoption of precision farming. Precision Agric., 12(1), 2-17. http://dx.doi.org/10.1007/s11119-009-9150-0

Lambert, D. \& Lowenberg-DeBoer, J. (2000). Precision agriculture profitability review. Site-specific Management Center, Purdue University, West Lafayette, IN, USA. 154 pp. http://www.agriculture.purdue.edu/ssmc/frames/newsoilsx.pdf

Lengnick, L.L. (1997). Spatial variation of early season nitrogen availability indicators in corn. Commun. Soil Sci. Plant Anal., 28(19-20), 1721-1736. http://dx.doi.org/10.1080/00103629709369912

Li, F., Miao, Y., Zhang, F., Cui, Z., Li, R., Chen, X., Zhang, H., Schroder, J., Raun, W.R., \& Jia, L. (2009). In-season optical sensing improves nitrogen-use efficiency for winter wheat. Soil Sci. Soc. Am. J., 73(5), 1566-1574. http://dx.doi.org/10.2136/sssaj2008.0150

Malchiri, R.J. (2008). Advances in the use of remote sensors in Argentinean agriculture. Better Crops, 94(3), 21-23.

Mann, C. (1997). Reseeding the green revolution. Science, 277(5329), 1038-1043. http://dx.doi.org/10.1126/science.277.5329.1038

Isaac, M.E., \& Kimaro, A.A. (2011). Diagnosis of nutrient imbalances with vector analysis in agroforestry systems. J. Environ. Qual., 40(3), 860-866. http://dx.doi.org/10.2134/jeq2010.0144

Martin, K. L., Girma, K., Freeman, K.W., Teal, R.K., Tubaña, B.S., Arnall, D.B., Chung, B., Walsh, O., Solie, J.B., Stone, M.L., \& Raun, W.R. (2007). Expression of variability in corn as influenced by growth stage using optical sensor measurements. Agron. J., 99(2), 384-389. http://dx.doi.org/10.2134/agronj2005.0268

Mellgren, R. (2008). Effect of irrigation and nitrogen treatments on yield, quality, plant nitrogen uptake and soil nitrogen status and the evaluation of sap test, SPAD chlorophyll meter and Dualex to monitor nitrogen status in broccoli. MSc.Thesis, Swedish University of Agricultural Science, Alnarp, Sweden. http://ex-epsilon.slu.se:8080/archive/00002291/

McBratney, A., Whelan, B., Ancev, T., \& Bouma, J. (2005). Future directions of precision agriculture. Precision Agric., 6(1), 7-23. http://dx.doi.org/10.1007/s11119-005-0681-8 
McKenzie, B.M., Bengough, A.G., Hallett, P.D., Thomas, W.T.B., Forster, B., \& McNicol, J.W. (2009). Deep rooting and drought screening of cereal crops: A novel field-based method and its application. Field Crops Res., 112 (2-3), 165-171. http://dx.doi.org/10.1016/j.fcr.2009.02.012

Miransari, M., \& Mackenzie, A.F. (2011). Development of a Soil N Test for fertilizer requirements for corn production in Quebec. Commun. Soil Sci. Plant Anal., 42(1), 50-65. http://dx.doi.org/10.1080/00103624.2011.528715

Mullen, R.W., Freeman, K.W., Raun, W.R., Johnson, G.V., Stone, M.L., \& Solie, J.B. (2003). Identifying an in-season response index and the potential to increase wheat yield with nitrogen. Agron. J., 95(2), 347-351. http://dx.doi.org/10.1081=PLN-120017134. 0190-4167

Mulvaney, R.L., Khan, S.A., Warren, J.J., Gonzini, L.C., Smith, T.J., \& Hoeft, R.G. (2004). Potential of the Illinois soil nitrogen test to improve nitrogen fertilizer management for corn production. In Proceedings of the Illinois Fertilizer Conference Jan. 26-28, University of Illinois at Urbana-Champaign, IL.

Najafabadi, M.O., Hosseini, S.J.F., \& Bahramnejad, S. (2011). A Bayesian confirmatory factor analysis of precision agricultural challenges. Afr. J. Agri. Res., 6(5), 1219-1225. http://www.academicjournals.org/AJAR

Nel, A.A., \& Bloem, A.A. (2007). Delta yield versus yield goal for estimating sunflower nitrogen fertilization rates in South Africa. HELIA, 30(47), 159-166. http://dx.doi.org/10.2298/HEL0747159N

Oboh, V.U., \& Ekpebu. I.D. (2011). Determinants of formal agricultural credit allocation to the farm sector by arable crop farmers in the Benue State, Nigeria. Afr. J. Agri. Res., 6(1), 181-185. http://www.academicjournals.org/AJAR

Oikeh, S.O., Houngnandan, P., Abaidoo, R.C., Rahimou, I., Touré, A., Niang, A., \& Akintayo, I. (2010). Integrated soil fertility management involving promiscuous dual-purpose soybean and upland NERICA enhanced rice productivity in the savannas. Nutr. Cycl. Agroecosyst., 88, 29-38. http://dx.doi.org/10.1007/s10705-008-9185-z

Okeleye, K. (2009). Influence of legume/rice sequence and nitrogen on nerica rice in rainfed upland and lowland ecologies of West Africa. In The Proceedings of the International Plant Nutrition Colloquium XVI, UC, Davis., CA. XVI. Retrieved July 19, 2011. http://escholarship.org/uc/item/1jr2m2h2

Paxton, K.W., Mishra, A.K.; Chintawar, S., Roberts, R.K., Larson, J.A., English, B.C., Lambert, D.M., Marra, M.C., Rambo, L., Ma, B-L., Xiong, Y., \&, da Silva, P.R.F. (2010). Leaf and canopy optical characteristics as crop-N-status indicators for field nitrogen management in corn. J. Plant Nutr. Soil Sci., 173(3), 434-443. http://dx.doi.org/10.1002/jpln.20090002

Raun, W.R., Solie, J.B., Johnson, G.V., Stone, M.L. Mullen, R.W., Freeman, K.W., Thomason, W.E., \& Lukina, E.V. (2002). Improving nitrogen use efficiency in cereal grain production with optical sensing and variable rate application. Agron. J., 94(4), 815-820. http://dx.doi.org/10.2134/agronj2002.8150

Raun, W.R., Solie, J.B., \& Stone, M.L. (2011). Independence of yield potential and nitrogen responsiveness. Precision Agric., 12(4), 508-518. http://dx.doi.org/10.1007/s11119-010-9196z

Raun, W.R., Solie, J.B., \& Stone, M.L., Martin, K.L., Freeman, K.W., Mullen, R.W., Zhang, H., Schepers, J.M., \& Johnson, G.V. (2005). Optical sensor based algorithm for crop nitrogen fertilization. Commun. Soil Sci. Plant Anal., 36(19-20), 2759-2781. http://dx.doi.org/10.1080/00103620500303988. 2759

Raun, W.R., Taylor, R., Solie, J.B., Stone, M.L., \& Arnall, B. (2011). Development and delivery of the second generation optical pocket sensor for maximizing nitrogen use efficiency in cereal production systems. Report presented to the Oklahoma Conservation Commission. Accessed August 1, 2011. http://nue.okstate.edu/Pocket_Sensor/(2011)\%203\%207\%20Final\%20Report\%20w\%20edits.doc

Reichardt, M., \& Jurgens, C. (2009). Adoption and future perspectives of precision farming in Germany: results of several surveys among different agricultural target groups. Precision Agric., 10(1), 73-94. http://dx.doi.org/10.1007/s11119-008-9101-1

Riaz, M., Mian, I.A., \& Cresser, M.S. (2011). How important is plant litter to the regulation of mineral-N leaching to streams in winter? An observations-led experimental approach. Soil Use Manage, 27(1): 10-17. http://dx.doi.org/10.1111/j.1475-2743.2010.00306.x

Roberts, D.F., Adamchuk, V.I., Shanahan, J.F. Ferguson R.B., \&, Schepers, J.S. (2009). Optimization of crop canopy sensor placement for measuring nitrogen status in corn. Agron. J., 101(1), 140-149. http://dx.doi.org/10.2134/agronj2008.0072x 
Scharf, P.C. (2001). Soil and plant tests to predict optimum nitrogen rates for corn. J. Plant Nutr., 24(6), 805-826. http://dx.doi.org/10.1081/PLN-100103775

Scharf, P., Kitchen, N.R., Sudduth, K.A., Lory, J., Stevens, G.W., Oliveira, L., Shannon, M., Palm, H., Davis, G.J., Vories, E.D., \& Dunn, D. (2010). Precision nitrogen fertilizer management of maize and cotton using crop sensors. In R.J. Gilkes, \& N. Prakongkep (Eds.) Proceedings, $19^{\text {th }}$ World Congress of Soil Science; Soil solutions for a Changing World, Aug. 1- 6, 2010, Brisbane, Australia. p.29-32.

Sen, A., Srivastava, V.K., Singh, M.K., Singh, R.K., \& Kumar, S. (2011). Leaf colour chart vis-a-vis nitrogen management in different rice genotypes. Am. J. Plant Sci., 2(2), 223-236. http://dx.doi.org/10.4236/ajps.2011.22024

Shaker, P., Dannhauser, C.S., \& P.S. Fouché. (2009). Ground measurement of NDVI, a tool for identification of desirable grass species Proceedings, African Crop Science Society Conference Sept. 28 - Oct. 2, 2009, Cape Town, South Africa. p.103-106.

Shanahan, J.F., Kithchen, N.R., Raun, W.R., \& Schepers, J.S. (2008). Responsive in-season nitrogen management for cereals. Comput. Electron. Agric., 61(1), 51-62. http://dx.doi.org/10.1016/j.compag.2007.06.006

Shapouri, S., \& Rosen, S. (2006). Degradation: Food aid needs in low-income countries. In R. Lal (ed.), Encyclopedia of Soil Science. 1(2), 425-427. Taylor and Francis LLC, NY. http://dx.doi.org/10.1081/E-ESS-120042657

Shaver, T.M., Khosla, R., \& Westfall, D.G. (2011). Evaluation of two crop canopy sensors for nitrogen variability determination in irrigated maize. In Press, Precision Agric. http://dx.doi.org/10.1007/s11119-011-9229-2.

Solari, F., Shanahan, J.F., Ferguson, R.B., \& Adamchuk, V.I. (2010). An active sensor algorithm for corn nitrogen recommendations based on a chlorophyll meter algorithm. Agron. J., 102(4), 1090-1098. http://dx.doi.org/10.2134/agronj2010.0009

Tian, Y., Zhu, Y., \& Kao, W. (2005). Monitoring_leaf_photosynthesis_with_canopy_spectral_reflectance_in_rice. Photosynthetica, 43(4), 481-489. http://dx.doi.org/10.1007/s11099-005-0078-y

Tremblay, N., Wang, Z., Ma, B-L., Belec, C., \& Vigneault, P. (2009). A comparison of crop data measured by two commercial sensors for variable-rate nitrogen application. Precision Agric., 10, 145-161. http://dx.doi.org/10.1007/s11119-008-9080-2

Tubaña, B.S., Arnall, D.B., Walsh, O., Chung, B., Solie, J.B., Girma, K., \& Raun. W.R. (2008). Adjusting midseason nitrogen rate using a sensor-based optimization algorithm to increase use efficiency in corn (Zea mays L.). J. Plant Nutr., 31, 1393-1419. http://dx.doi.org/10.1080/01904160802208261

Tubaña, B.S., Harrel, D., Walker, T., \& Phillips, S. (2011). Midseason nitrogen fertilization rate decision support tool for rice using remote sensing technology. Better Crops, 95(1), 22-24.

Ustin, S., Smith, M., Jacquemoud, S., Verstraete, M., \& Govaerts, Y. (1998). GeoBotany: Vegetation mapping for Earth Sciences. In A. Rencz (Ed.), Manual of remote sensing, 3, 189-248. John Wiley \& Sons, Hoboken, NJ.

Vanlauwe, B., \& Giller, K.E. (2006). Popular myths around soil fertility management in sub-Saharan Africa. Agric. Ecosys. Environ., 116(1-2), 34-46. http://dx.doi.org/10.1016/j.agee.2006.03.016

Vanlauwe, B., Tittonell, P., \& Mukalama, J. (2007). Within-Farm soil fertility gradients affect response of maize to fertiliser application in western Kenya. In A. Bationo, B. Waswa, J. Kihara, \& J. Kimetu (Eds.), Advances in integrated soil fertility management in sub-Saharan Africa: Challenges and opportunities. 121-132. Springer.

Varvel, G.E., Wilhelm, W.W., Shanahan. J.F., \& Schepers, J.S. (2007). An algorithm for corn nitrogen recommendations using a chlorophyll meter based sufficiency index. Agron. J., 99(3), 701-706. http://dx.doi.org/10.2134/agronj2006.0190

Vaughan, J.D., \& Hoyt, G.D. (2008). Evaluation of a quick test method for tobacco petiole nitrate analyses. Tob. Sci., 47, 11-12. http://dx.doi.org/10.3381/1960.1

Verhulst, N., Govaerts, B. Nelissen, V., Sayre, K.D., Crossa, J., Raes, D., \& Deckers, J. (2011). The effect of tillage, crop rotation and residue management on maize and wheat growth and development evaluated with an optical sensor. Field Crops Res., 120(1), 58-67. http://dx.doi.org/10.1016/j.fcr.2010.08.012 
Witt, C., Pasuquin, J.M., Pampolino, M.F., Buresh, R.J., \& Dobermann, A. (2009). A manual for the development and participatory evaluation of site-specific nutrient management for maize in tropical, favorable environments. IPNI, Penang, Malaysia. $30 \mathrm{pp}$.

Xu, Z., Guan, Z., Jayne, T.S., \& Black, R. (2009). Factors influencing the profitability of fertilizer use on maize in Zambia. Agric. Econ., 40(4), 437- 446. http://dx.doi.org/10.1111/j.1574-0862.2009.00384.x

Xue, L.H., \& Yang, L.Z. (2008). Recommendations for nitrogen fertiliser topdressing rates in rice using canopy reflectance spectra. Precision Agric., 100(4), 524-534. http://dx.doi.org/10.1016/j.biosystemseng.2008.05.005

Zamykal, D., \& Everingham, Y.L. (2009). Sugarcane and precision agriculture: quantifying variability is only half the story - A review. In E. Lichtfouse (Ed.), Climate change, intercropping, pest control and beneficial microorganisms. Sustainable Agriculture Reviews 2, 189-218. Springer. http://dx.doi.org/10.1007/978-90-481-2716-0_9

Zerfu, D., \& Larson, D.F. (2010). Incomplete markets and fertilizer use evidence from Ethiopia. Policy Research Working Paper. 5235. World Bank.

Zhang, H., Lan, Y., Lacey, R., Hoffmann, W.C., Martin, D.E., Fritz, B., \& Lopez Jr., J. (2010). Ground-based spectral reflectance measurements for evaluating the efficacy of aerially- applied glyphosate treatments. Biosys. Eng., 107(1), 10-15. http://dx.doi.org/10.1016/j.biosystemseng.2010.06.006

Table 1. Commonly available methods for field diagnostic plant $\mathrm{N}$ status

\begin{tabular}{|c|c|c|}
\hline Measured characteristics & Related techniques & References \\
\hline \multirow[t]{2}{*}{ Petiole sap nitrate concentration } & $\begin{array}{l}\text { Nitrate specific electrodes (Cardy meter, } \\
\text { Hatch) }\end{array}$ & $\begin{array}{l}\text { Cartelat et al. (2005); Hartz } \\
\text { (2007); Mellgren (2008) }\end{array}$ \\
\hline & $\begin{array}{l}\text { Nitrate test strips + reflectometer; } \\
\text { Quick-test }\end{array}$ & $\begin{array}{l}\text { Thompson et al. (2009); } \\
\text { Vaughan and Hoyt (2005) }\end{array}$ \\
\hline Leaf color & Leaf color chart & $\begin{array}{l}\text { Alam et al. (2005); Sen et al. } \\
(2011)\end{array}$ \\
\hline $\begin{array}{l}\text { Leaf chlorophyll concentration } \\
\text { (transmittance) }\end{array}$ & $\begin{array}{l}\text { Minolta Soil Plant Analysis Development } \\
\text { (Minolta } 502 \text { SPAD meter) }\end{array}$ & $\begin{array}{l}\text { Solari et al. (2010); Varvel et } \\
\text { al. (2007) }\end{array}$ \\
\hline $\begin{array}{l}\text { Leaf chlorophyll fluorescence } \\
\text { and absorbance by polyphenolic } \\
\text { compounds }\end{array}$ & $\begin{array}{l}\text { Dualex }^{\circledR} \text { (near sensing), } \\
\text { Multiplex }{ }^{\circledR} \text { (near remote sensing); } \\
\text { MiniVegN }\end{array}$ & $\begin{array}{l}\text { Huang et al. (2008); } \\
\text { Kuckenberg et al. (2008); } \\
\text { Mellgren (2008); }\end{array}$ \\
\hline \multirow[t]{4}{*}{ Crop light reflectance } & Cropscan (Multi-spectral sensor) & $\begin{array}{l}\text { Rambo et al. (2010); Scharf et } \\
\text { al. (2010); Xue and Yang } \\
\text { (2008) }\end{array}$ \\
\hline & $\begin{array}{l}\text { Yara sensor/Hydro-N-Tester (measures N } \\
\text { status from leaf chlorophyll content }\end{array}$ & $\begin{array}{l}\text { Berntsen et al. (2009); } \\
\text { Tremblay et al. (2009) }\end{array}$ \\
\hline & Crop Circle & $\begin{array}{l}\text { Kitchen et al. (2010); Roberts } \\
\text { et al. (2009) }\end{array}$ \\
\hline & GreenSeeker $^{\mathbb{B}}$ & $\begin{array}{l}\text { Bowen et al. (2005); Raun et } \\
\text { al. (2002); Velurst et al. } \\
\text { (2011) }\end{array}$ \\
\hline
\end{tabular}


Table 2. Challenges to adoption of precision agriculture in SSA

\begin{tabular}{|c|c|c|c|}
\hline Constraints & Common explanations & References & Opportunities \\
\hline Economics & $\begin{array}{l}\text { Includes high initial cost of } \\
\text { equipment, cost of training and } \\
\text { information gathering }\end{array}$ & $\begin{array}{l}\text { Kutter et al. (2009); } \\
\text { Reichardt et al. } \\
(2009)\end{array}$ & $\begin{array}{l}\text { Opportunity for } \\
\text { co-ownership, especially for } \\
\text { cooperative farms }\end{array}$ \\
\hline Education & $\begin{array}{l}\text { Dearth/absence of functional } \\
\text { support tools. Scarcity of } \\
\text { professionally trained precision } \\
\text { agriculture experts in SSA, nor do } \\
\text { universities offer precision } \\
\text { agriculture in their curricula }\end{array}$ & $\begin{array}{l}\text { Mcbratney et al. } \\
\text { 2005; Najafabadi et } \\
\text { al. (2011) }\end{array}$ & $\begin{array}{l}\text { Increasing new generation of } \\
\text { farmers in SSA is more } \\
\text { literate and innovative to } \\
\text { surely grasp concepts and } \\
\text { opportunities. Access to } \\
\text { internet network for } \\
\text { information sharing }\end{array}$ \\
\hline Time & $\begin{array}{l}\text { Time needed to train personnel, } \\
\text { train extension agents and } \\
\text { convince farmers to adopt a } \\
\text { practice can be very long. Long } \\
\text { turnover time from investment }\end{array}$ & $\begin{array}{l}\text { Reichardt \& Jurgens } \\
\text { (2009) }\end{array}$ & $\begin{array}{l}\text { Short time frame is needed } \\
\text { between collection of sensor } \\
\text { data and determination of } \\
\text { recommended input rates; } \\
\text { free online access to } \mathrm{N} \text { input } \\
\text { rate calculator }\end{array}$ \\
\hline $\begin{array}{l}\text { Incompatibility } \\
\text { (software and } \\
\text { equipment) }\end{array}$ & $\begin{array}{l}\text { Where applicable, difficulty with } \\
\text { retrofitting sensors to existing } \\
\text { equipment in case of on-the-go } \\
\text { fertilizer applicators }\end{array}$ & Kutter et al. (2009) & $\begin{array}{l}\text { Variable rate applicators not } \\
\text { needed. Handheld sensors } \\
\text { more suitable for } \\
\text { smallholder farmers }\end{array}$ \\
\hline Risk/Uncertainty & $\begin{array}{l}\text { Existing alternative farming } \\
\text { technologies make adoption less } \\
\text { attractive }\end{array}$ & $\begin{array}{l}\text { Cook et al. (2003); } \\
\text { Gandonou (2005); }\end{array}$ & $\begin{array}{l}\text { Potentially profitable for risk } \\
\text { averse and high input use } \\
\text { farmers; opportunity for } \\
\text { co-ownership, especially for } \\
\text { cooperative farms }\end{array}$ \\
\hline $\begin{array}{l}\text { Data collection, } \\
\text { handling, and } \\
\text { delivery }\end{array}$ & $\begin{array}{l}\text { Special skills needed to collect, } \\
\text { process, interpret data and relay } \\
\text { the information to farmers to be } \\
\text { able to use }\end{array}$ & $\begin{array}{l}\text { Cook et al. (2003); } \\
\text { Reichardt and } \\
\text { Jurgens (2009) }\end{array}$ & $\begin{array}{l}\text { Opportunities for personnel } \\
\text { training, record keeping, } \\
\text { research results update } \\
\text { validation, planning. } \\
\text { Improved internet access. }\end{array}$ \\
\hline Technical & $\begin{array}{l}\text { Level of technology knowhow is } \\
\text { still very low; Equipment are } \\
\text { mostly sophisticated and } \\
\text { non-robust }\end{array}$ & Gandonou (2005) & $\begin{array}{l}\text { New developments of } \\
\text { cheaper sensors (pocket } \\
\text { sensor) are promising. } \\
\text { Calibration of sensors not } \\
\text { necessary with available rate } \\
\text { calculator on-line }\end{array}$ \\
\hline Demographics & $\begin{array}{l}\text { Most of the farmers over a certain } \\
\text { age are often less willing to try } \\
\text { newly developed technologies } \\
\text { applicable to farming }\end{array}$ & Paxton et al. (2011) & $\begin{array}{l}\text { More suited for younger or } \\
\text { educated and innovative } \\
\text { farmers }\end{array}$ \\
\hline
\end{tabular}




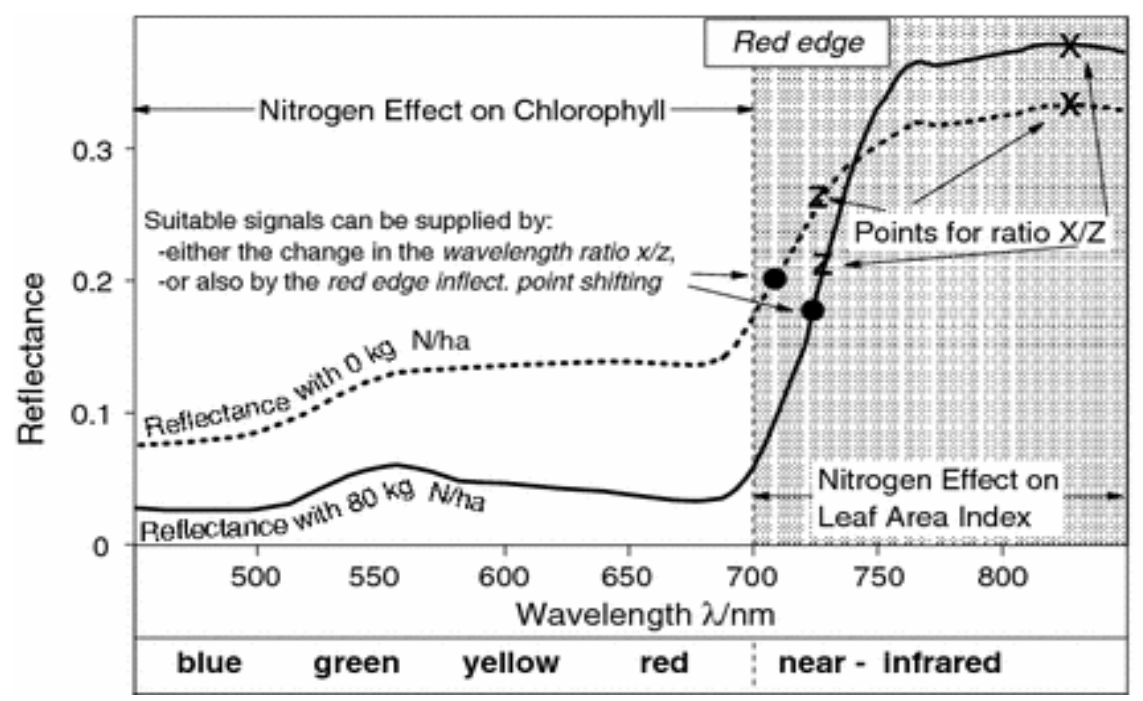

Figure 1. Reflectance of winter rye at second top-dressing based on the $\mathrm{N}$ spread 7weeks earlier (Hegee et al., 2008)

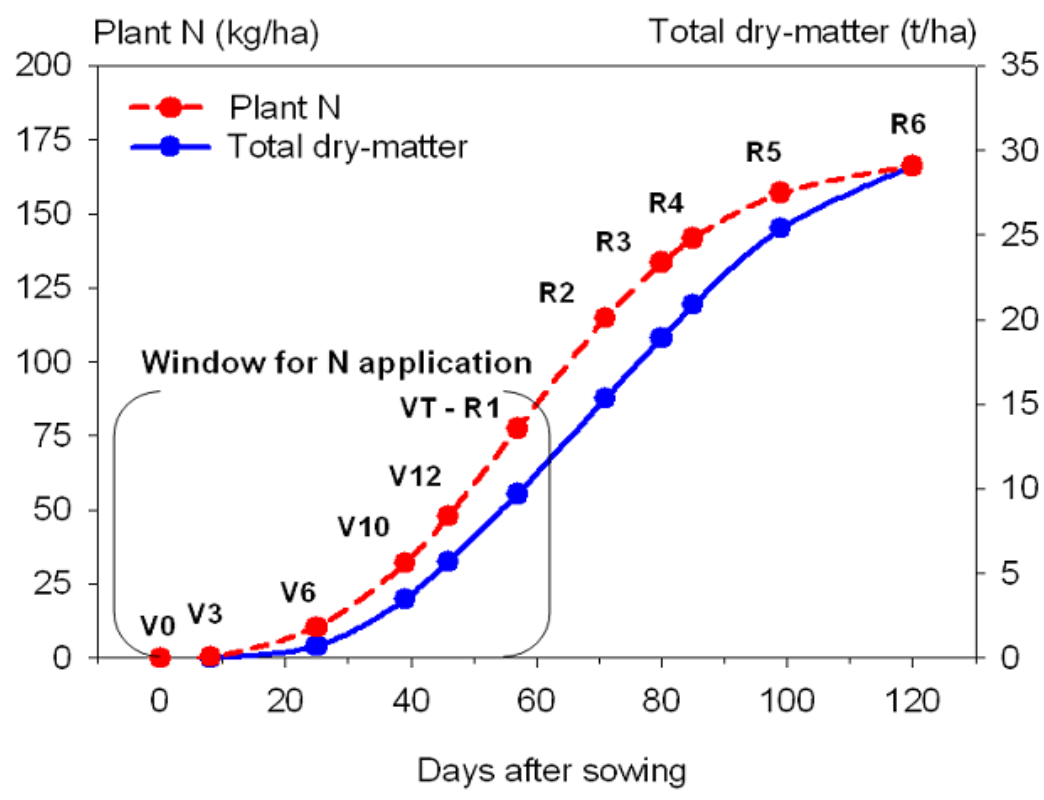

Figure 2. Schematic representation of plant $\mathrm{N}$ demand depending on growth stage (Witt et al., 2009) 